to his students on "The Classification of Animals" appeared in book form in 1949.

As administrator of a large museum department, subordinates of all grades found him most approachable. To the younger zoologists of his staff he gave freely of his time, knowledge and experience, and as an editor he excelled. Sociable by nature, he liked to meet all visitors to his Department, whether student or foreign specialist (with whom on occasion he had to converse in Latin). All who knew him appreciated his profound erudition, his great personal charm and his sense of humour. His memory is held in affectionate esteem by all who came under his influence.

In 1906 he married Miss Alice Donaldson, of Tayport, who, with a son and a daughter, survives him.

I. GORDON

\section{Prof. F. C. Lea, O.B.E.}

Prof. F. C. Lka, emeritus professor of engineering in the University of Sheffield, died on September 30 at the age of eighty-one.

Frederick Charles Lea was born near Crewe and was apprenticed in the Mechanical and Electrical Departments of the London and North Western Railway. $\mathrm{He}$ received his scientific education at Owens College, Manchester, and the Royal College of Science, London. He was Senior Whitworth Scholar in 1896. After a further period with the London and North Western Railway, he became in 1900 senior assistant to Prof. W. C. Unwin at the City and Guilds of London Central Technical College. In 1908 he published the text-book on "Hydraulics" by which his name became known to engineering students all over the world. During 1911-13 he served as one of H.M. inspectors of technical education and in 1913 was appointed professor of civil engineering in the University of Birmingham.

During the First World War he held commissions, first in the Territorial Force and afterwards in the R.N.V.R. and in the R.A.F. He made a special study of materials for aircraft and was concerned in the development of all-metal aeroplanes.

In 1923 Prof. Lea was appointed professor of mechanical engineering in the University of Sheffield, and was dean of the Faculty of Engineering until his retirement in 1936. During this period he carried on experimental research, in association with a succession of students, in several fields related to the mechanical properties of metals, and he published numerous papers on such subjects as fatigue, embrittlement, welded joints, springs, and notably creep at high temperatures.

During his career, Lea took a lively interest in scientific and technical societies, and was perhaps specially attached to the British Association and to the Institution of Mechanical Engineers. $\mathrm{He}$ was president of Section G (Engineering) of the former in 1929 and of the Institution in 1944. He served on many committees and consultative bodies concerned with technical and educational matters, and had a considerable part in the development of the National Certificate schemes. During 1936-50 he, was a director of Edgar Allen and Co., Sheffield.

Lea's contribution in the field of engineering science was a dual one: on one hand, he was a skilful and energetic experimental investigator with a wide range of interests; on the other, he was a progressive technical educationist and a particularly able teacher. His influence to-day is probably mainly felt through the hundreds of engineering graduates to whom he communicated enthusiasm and the spirit of inquiry.

In his personal life, Lea was a deeply religious man and had a high sense of social duty. Throughout his life he was an active member of the Methodist Church, and he served it in many capacities both in administration and as teacher and speaker. For several years he presided over the Sheffield Council for Social Service.

\section{Mr. Peter Doig}

We regret to announce the death on October 13 , after a long illness, of Mr. Peter Doig. He was born in 1882 in Glasgow, where he received his primary education and later he was trained as a draughtsman at the shipyard of John Brown and Co., Ltd., at Clydebank. He then worked at Harland and Wolff's, Belfast, and afterwards at shipyards in Shanghai, where a serious breakdown in health in 1916 necessitated a temporary rest, and he returned to Clydebank, travelling by the Trans-Siberian Railway to Europe. After working for a time at Beardmore's, he went to the United States, and on his return was appointed in 1918 general secretary of the Association of Engineering and Shipbuilding Draughtsmen. $\mathrm{He}$ did very good work on screw propeller design, on which he had specialized; but unfortunately illhealth compelled him to retire from the secretaryship of his Association in 1945.

Doig was a keen astronomer, and was elected a member of the British Astronomical Association in 1921 and a Fellow of the Royal Astronomical Society the following year. In 1930 he was appointed editor of the Journal of the British Astronomical Association, a position which he held until 1937, when the pressure of work with his professional Association compelled him to resign; but in 1948, after his retirement as secretary of his Association, he was re-appointed editor of the Journal and continued with this work until his death. He was an excellent editor, and made considerable contributions himself to the Journal in the form of reviews and notes from numerous astronomical publications in various parts of the world. During 1928-4I he was also honorary curator for the British Astronomical Association. In 1927 his book, "An Outline of Stellar Astronomy", was published, and an enlarged and revised edition appeared in 1947 ; in 1950 " $A$ Concise History of Astronomy" was published, a book which deals with the history of astroncmy from the earliest times up to recent years. During 1951-52 he collaborated with eleven other astronomers-each an authority in his own particular subject-in the production of a work on astronomy in which he was responsible for the larger portion of the chapter on the historical side and sole author of the chapter on the stars ; he had corrected the paged proofs shortly before he died.

In $1909 \mathrm{Mr}$. Doig married Mary Scott, who, with a married daughter, survives him.

WE regret to announce the following deaths :

Prof. J. G. Lawn, C.B.E., president, in 1930 of the Institution of Mining and Metallurgy, on October 21, aged eighty-four.

Prof. Ernest Vessiot, member of the Mechanics Section of the Paris Academy of Sciences and formerly director of the Ecole Normale Supérieure, Paris, on October 17, aged eighty-seven. 